David BOLE

Mateja BREG VALJAVEC

Bojan ERHARTIČ

Drago KLADNIK

Katarina POLAJNAR

Aleš SMREKAR

\title{
Assessing the suitability of planned garden-plot areas in Ljubljana
}

This article examines garden plots in Ljubljana to present the planning of this self-sufficient vegetable production activity, which developed mostly spontaneously in all urban environments in and around Ljubljana. Some residents of Ljubljana, the Slovenian capital, are involved in this activity not so much because of economic necessity but because it provides recreation and relaxation, meets their need for direct contact with nature, and offers them an opportunity to produce healthy food. Typically, older people are involved in this activity, among which the number of highly educated people is unexpectedly high. The majority are happy with the plot-gardening situation. The city government has begun systematically removing garden plots in unsuitable locations, and has drafted a proposal to organize gardening areas in a way that does not pollute the environment, and at the same time provide them with suitable infrastructure. We evaluated the appropriateness of the planned locations in the draft City Municipality of Ljubljana Zoning Implementation Plan on the basis of the fulfillment of key exclusion and attraction criteria that were established based on survey answers included in support of the decision-making with the help of GIS tools. Decision-making by consensus, inclusion of public stakeholders, and establishing dialog between the city government and garden-plot users will need to be ensured in carrying out this plan.

Key words: plot gardening, leisure activity, garden-plot users, zoning implementation plan, Ljubljana 


\section{Introduction}

In cities, nature is present in various forms of urban green areas: city parks, tree-lined avenues, historic gardens, other green areas, and gardens and garden plots. Green areas in the city core are an environment in which people can meet their need for contact with nature. City-dwellers are most accepting of areas with safe and predictable natural features, and they find this in urban green areas. They are continuously seeking new, more direct contact with nature, which must be taken into account by city officials and planners in line with an emphasis on tolerance and understanding of diversity (Simoneti, 2000).

Plot gardening is a multipurpose activity. Its primary purpose is producing vegetables for personal needs and the needs of the owners' extended families. It takes place in gardens that are not a part of the private plots surrounding individual residential buildings, and are usually at a separate location. These are basically tenant plots with a relatively small area for cultivation, which is usually a part of a larger plot area. The activity is non-commercial because the produce is usually not sold.

Even though cities are built up and contain very few redundant empty spaces, garden-plot areas are always found in places that (at least for a certain period) are not attractive for other activities. For example, they are found in abandoned urban lots, along streams, under power lines, along roads and other traffic routes, and around apartment buildings. The greatest potential for plot-gardening development is provided by large areas of public land protected by the city government as land not zoned for development due to landscaping, city expansion, and groundwater protection.

In Ljubljana, long-term insufficient control and insufficient environmental awareness of garden-plot users could lead to dangerous and harmful effects of plot gardening, especially because this activity is mostly carried out in environmentally sensitive areas. Some plot-gardening areas have gradually begun changing into areas used for recreation and garden-plot huts without building permits, without legal driveways, and with unsanitary conditions, illegal water consumption, and unregulated accumulation of waste from pest-control products.

The city government decided to put a stop to such behavior. It began gradually eliminating illegal garden plots in environmentally sensitive areas where they were the most intrusive while trying to provide allotments for more organized, managed, and controlled forms of plot gardening. It drafted proposals that included approximately 30 garden-plot locations. The appropriateness of this choice, which we investigated as a part of a special study (Vrščaj et al., 2008), including the methodo- logy used, is discussed in detail in the second part of this article. Appropriately selected locations are key for further developing this very popular activity among the people of Ljubljana.

First, we detail the main characteristics of the development of plot gardening in Ljubljana to date and Ljubljana's garden-plot users, which were examined in much greater detail in the study mentioned above (ibid.). We found ourselves at a crossroads at which this activity is being profoundly transformed, even though the garden-plot users' motives have not changed much in recent years. This is why our most recent survey data are becoming dated.

The survey included no fewer than 150 questions (with numerous sub-questions) in the following areas:

- Garden-plot location and equipment

- Garden-plot area characteristics

- Land-ownership conditions

- Social and economic indicators

- Motivation for plot gardening

- Garden-plot users' attitude towards the environment

- Garden-plot users' attitude towards soil

- Garden-plot users' attitude towards groundwater

- Familiarity with water-protection areas

- Fertilizer use (time and quantity)

- Pest-control use (time and quantity)

- Produce

- Willingness to change the garden-plot location.

The survey area was chosen following these criteria:

- Garden-plot location in relation to the water-protection area

- Soil characteristics

- Potential location of pollution sources

- Garden-plot area size

- Equal distribution of garden-plot areas within existing areas in the City Municipality of Ljubljana.

The survey was carried out from 11 July to 30 August 2006. A total of 302 surveys were distributed in 34 existing gardenplot areas. Initially, 33 areas were designated to be surveyed, and 9 surveys were to be given out in each area. The fieldwork showed that a larger number of surveys needed to be given out in certain areas due to the insufficient willingness of potential respondents in other areas, and so two additional garden-plot areas were also included. Six to nine garden-plot users completed our survey in some areas, as few as one in one area, and as many as 19 in the largest survey area. Only in one area (along Fajfarjeva ulica 'Fajfar Street' in Vič) were no surveys completed because the garden-plot users refused to cooperate. We believe that an approximately $50 \%$ share of the surveyed garden-plot user population sufficiently meets the require- 
ments of representative sampling, and enables generalization of the findings, determination of general behavior patterns, and formation of generally valid conclusions.

We should also mention that all of us involved in the study titled Plot gardening in the City Municipality of Ljubljana as a pollution source for soil, food produced, and groundwater (Vrščaj et al., 2008) consider it fortunate that research on plot gardening and garden-plot owners in Ljubljana is repeated every few years, which also enables comparative analyses. Because this issue is in some way or another evident to everyone, and is connected with various aspects and issues of urban spatial development, it is of no surprise that it is of interest to a wide circle of researchers. The first major study was conducted in the mid-1980s (Goriup, 1984). The study Guidelines and conditions for further development of plot gardening in Ljubljana (Simoneti et al., 1997) was very extensive. Research was also conducted by architects (Vastl, 2000). In the early years of the twenty-first century, the City Municipality of Ljubljana became increasingly aware of the problem of regulating the increasing spontaneous development of plot gardening. Therefore, the first regulatory study was conducted (Gregorič et al., 2004; Doležal et al., 2005). The expert groundwork for garden-plot area management (Simoneti et al., 2007) was completely innovative and serves as the basis for the Zoning Implementation Plan (City Municipality of Ljubljana, 2008).

\section{Basic characteristics of garden plots in Ljubljana}

More detailed data on the distribution and the area of garden plots in Ljubljana have been available only in the past few decades (Table 1).

In 1984, when plot gardening was in full bloom in Ljubljana, garden plots covered an area of exactly 2 square kilometers in 289 locations. Spontaneously developing garden-plot areas were distributed across the entire flat area of Ljubljana. By 1995, the total area of plot gardens had increased by one-third to $2.67 \mathrm{~km}^{2}$, and the number of garden-plot areas reached its peak at 378. By 2005, the area of garden plots and the number of garden-plot areas had receded due to a changed, more urban lifestyle, and reached lower levels than in 1984 . The greatest

Table 1: Change in the area of garden plots in Ljubljana and in the number of garden-plot areas between 1984 and 2008.

\begin{tabular}{lrrrr}
\hline Year & 1984 & 1995 & 2005 & 2008 \\
\hline Area $\left(\mathrm{km}^{2}\right)$ & 2.00 & 2.67 & 1.86 & 1.30 \\
\hline Number of areas & 289 & 378 & 249 & 218 \\
\hline
\end{tabular}

Source: Goriup (1984), Simoneti et al. (1997), Surveying and Mapping Authority of the Republic of Slovenia (2005), Vrščaj et al. (2008). regression was recorded in locations within the densest part of the city or on its edge because these areas are more exposed to intense construction. The active interference of the city government also caused the number of garden-plot areas to fall to 218 by 2008, and the garden-plot area shrank to a mere 1.30 $\mathrm{km}^{2}$, which is one-third of its previous size.

Garden-plot areas vary in size, from a few dozen square meters to a few dozen hectares. Plot gardening is known by its tenant structure. Only $7 \%$ of the garden-plot users surveyed also own the plots they use. Among 93\% of surveyed tenants, less than one-half ( $43 \%$ ) actually rent the land, and the rest (half of all surveyed garden-plot users) are squatting on "no man's land," for which they naturally pay no rent. No fewer than threequarters of garden-plot users have never signed a contract, and $91 \%$ stated that they do not wish to rent out additional plots for further plot gardening or potential expansion. Only onethird of those surveyed would also like to purchase their plot.

The plot-gardening phenomenon in Ljubljana is not merely of economic significance or for food production. This is confirmed by the fact that a large number of garden plots include an ornamental garden (28.5\%) or a small lawn (26.5\%). A surprisingly large number of garden-plot users surveyed have an orchard on their plot $(26 \%)$, and even a vineyard (20\%) or, more precisely, a grape trellis.

We discovered (Vrščaj et al., 2008) that in 2005 the area of an average garden plot in Ljubljana amounted to $205 \mathrm{~m}^{2}$. Half of this area $\left(101 \mathrm{~m}^{2}\right)$ was intended for vegetable production (Figure 1). On average, a relatively large area was taken up by the yard (just over one quarter or $55 \mathrm{~m}^{2}$ ); there were significantly more unpaved yards than paved ones. On average, $16 \mathrm{~m}^{2}$ or $8 \%$ of the garden-plot area was covered by an orchard, which made the area with the grapevines significantly smaller $\left(6 \mathrm{~m}^{2}\right.$ or $3 \%)$. In an average garden plot, $8 \mathrm{~m}^{2}(4 \%)$ was covered by a lawn, and an ornamental garden covered $5 \mathrm{~m}^{2}(2.4 \%)$.

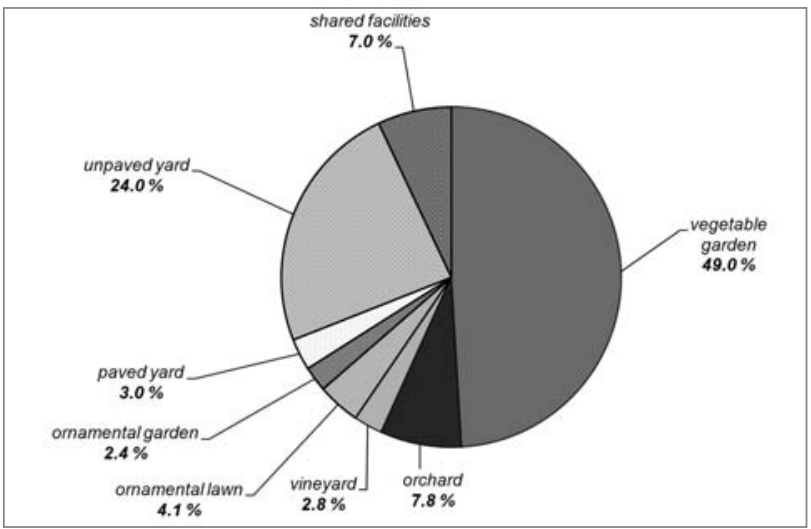

Figure 1: Land use in Ljubljana's garden plots in 2005 (source: Vrščaj et al., 2008). 
Garden-plot areas are not well equipped with infrastructure. The majority (235) are accessible via driveways; however, these driveways are usually unsurfaced and poorly maintained. Only $15 \%$ of garden-plot areas are said to be connected to the public sewage system, and electrical hookups occur only exceptionally.

Only a small number of garden-plot areas include shared facilities: along Saveljska cesta (Savlje Street) in Savlje, Bratislavska cesta (Bratislava Street) in Moste, and Cesta dveh cesarjev (Two Emperors Street) in Vič. Some have common restrooms (12) and common waste disposal (14). Among the areas with restrooms, five have chemical toilets, and two are connected to the public sewage system; both of these are in Krakovo, which is otherwise best equipped with municipal infrastructure (ibid.).

Unlike garden-plot areas in Austria (surveyed in the field in the Vienna and Graz areas), Germany, or Switzerland (Christl et al., 2004), garden-plot areas in Ljubljana are usually not enclosed; however, many garden-plot users (114 or 38\%) have bounded and protected "their" land with enclosures, mostly (38) brick walls, and more rarely with wire fences (30), hedges (29), and wooden fences (14).

Two-thirds of garden-plot users have a building on their plot (Vrščaj et al., 2008). The area of an average building amounts to $14 \mathrm{~m}^{2}$ and covers approximately $7 \%$ of the plot's area. The buildings have no blueprints, their construction was unplanned, and a wide variety of materials were used. They resemble makeshift shacks and therefore do not contribute to the attractiveness of the garden-plot areas. In many cases, these huts are not merely simple sheds for tools and produce, but actual vacation shacks. The prevailing material used for the walls is wood; no less than $93 \%$ are wooden buildings. The remaining buildings are mostly made of sheet metal. The survey indicates that only four buildings have masonry construction; three are made of brick, and one of concrete. A cause for concern is the fact that the prevailing roofing is corrugated asbestos-cement roof panels (a full 64\%). Even though these carcinogenic panels made at the Anhovo Cement Factory have been replaced in most residential and other buildings around Slovenia, garden plots in Ljubljana give the impression that the owners are not particularly interested in replacing this dangerous roofing.

\section{Garden-plot users in Ljubljana}

In Ljubljana, tenants of small plots started appearing at the beginning of the twentieth century, when these allotments were used as vegetable gardens (Vastl, 2000). They may be regarded as the first garden-plot users. Until the end of the Second World War, there were two main reasons for the development of plot gardening:

- Adding private open space to an insufficient dwelling area, and
- Guaranteeing a subsistence level for the lowest social stratum through vegetable and fruit production, and raising small animals.

After the Second World War, the reasons for plot gardening changed drastically. It was no longer needed for provision; rather, its main function was relaxation and recreation.

A small percentage of Ljubljana's inhabitants are active plot gardeners. The precise figure is unknown, but a study from a decade ago (Simoneti et al., 1997) roughly estimated that at least 12,000 residents of Ljubljana were involved in plot gardening in the 1990s. More realistically, the number was probably closer to 13,500 . Given that we recorded a substantial decrease in the size of plot-gardening areas in 2005, we can conclude with certainty that the number of active garden-plot users has decreased to fewer than 10,000 (Vrščaj et al., 2008).

The decrease in the number of garden-plot users does not mean that the needs for such leisure activity are significantly decreasing. Plot gardening is an activity largely passed from one generation to the next. This is confirmed by the results of a study carried out in the 1980s (Goriup, 1984), which revealed that $88.6 \%$ of garden-plot users come from families that had a garden and they were therefore attached to gardens since childhood. Just because many of these people are immigrants does not imply that they have plot-gardening roots; however, it does imply that they had a certain contact with gardens in the environment prior to moving to Slovenias capital. The same study showed a surprising consistency and tenaciousness of garden-plot users. Over time, only one-sixth of garden-plot users have stopped cultivating their gardens, mainly due to illness or similar reasons.

A recent study (Vrščaj et al., 2008) included 302 people in charge of garden plots, but there were 551 people involved in plot gardening altogether. An individual garden plot in Ljubljana is most frequently regularly cultivated by two people (54.0\%), and almost exactly one-third (33.8\%) are cared for by one person. Just under one-tenth of garden plots (8.3\%) are regularly taken care of by three people. In the case of two caretakers, this is usually a married couple. On average, a plot gardener spends an hour and a half per day in his garden. It is noteworthy that this time is shorter than the two to three hours mentioned in the study from the 1980s (Goriup, 1984). Reduced time spent in gardens is certainly a result of the stricter working conditions that came about with modern social and political changes.

There are slightly more women than men among garden-plot users $(54.1 \%$ vs. $45.9 \%)$, which must also be due to their higher life expectancy. Plot gardening is the domain of senior 
citizens (Figure 2). This is confirmed by the calculation that the average age of a Ljubljana garden-plot user is 60.6 (Vrščaj et al., 2008). It is interesting that the average age of a Zürich garden-plot user is also 61 (Christl et al., 2004). At the time of surveying, the youngest plot gardener in Ljubljana was 26 and the oldest 89 years old.

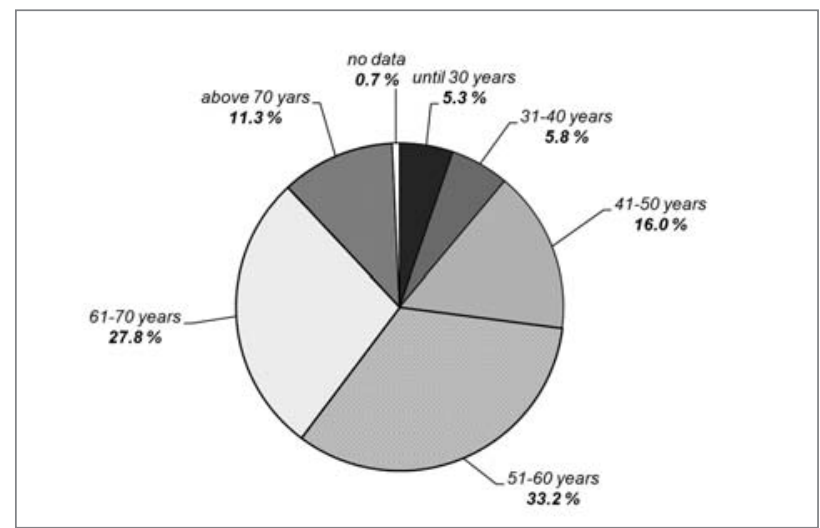

Figure 2: Age structure of regular plot gardeners (source: Vrščaj et al., 2008).

the education level of Ljubljana residents as a whole (Vrščaj et al., 2008). This gap is particularly evident in the category of people with a junior-college education (24.2\% among all Ljubljana residents, and $11.8 \%$ among garden-plot users; this is more than expected, and indicates that plot gardening is an important value in the lives of many educated people); however, the differences are considerably smaller in the other three education categories. The shares in all lower categories are slightly larger among plot gardeners. $31.1 \%$ of gardeners graduated from a four- or five-year high school (versus 33.1\% of Ljubljana residents), 23.4\% graduated from a two-or threeyear vocational school (versus $21.0 \%$ of Ljubljana residents), and $23.8 \%$ either graduated from or only attended primary school (versus $21.5 \%$ of Ljubljana residents).

The percentage of plot gardeners in Ljubljana with a university education is slowly decreasing, shown by the fact that two decades ago this percentage was 12.6\% (Goriup 1984, 47). One must be careful when interpreting this information because it must be taken into account that the average education level has significantly increased since then. This means that the significance of plot gardening among university-educated people is, partly unexpectedly, not decreasing. One might even say that it is gaining value.

A full half of Ljubljana's plot gardeners are retired (53.4\%), and one-third (32.8\%) are employed. The percentage of all other population groups is significantly smaller. A relatively large portion consists of unemployed plot gardeners (5.6\%). This percentage, however, does not deviate from the average of unemployed residents of Ljubljana (Vrščaj et al., 2008).
Our most recent study does not address ethnic structure. The study from more than twenty years ago (Goriup, 1984), however, reveals that among plot gardeners the percentage of citizens born in the other republics or two autonomous provinces of the former Yugoslavia was much higher than that among the entire population of Ljubljana. In the 1980s, more than one-fifth of garden-plot users were born outside of Slovenia.

Plot gardening is a leisure activity for city dwellers confined in apartment block neighborhoods, row houses, and detached houses on extremely small lots where there is no room for a garden, or a private plot or green area in the immediate vicinity of the building. It is especially the residents of multistory buildings or apartment blocks in densely built-up residential areas that feel the need for at least a short escape to their garden plots and contact with nature. The areas they live in do not allow people to express their individuality outside of their apartments (Figure 3). Nearly three-fifths of plot gardeners surveyed (59.3\%) belong to this category. Just under one-fourth $(22.8 \%)$ come from apartment blocks or multistory buildings that are not in densely built-up areas. $8.6 \%$ of gardenplot users live in detached single-family houses, and $7.9 \%$ live in multi-apartment residential buildings with fewer than five apartments (Vrščaj et al., 2008).

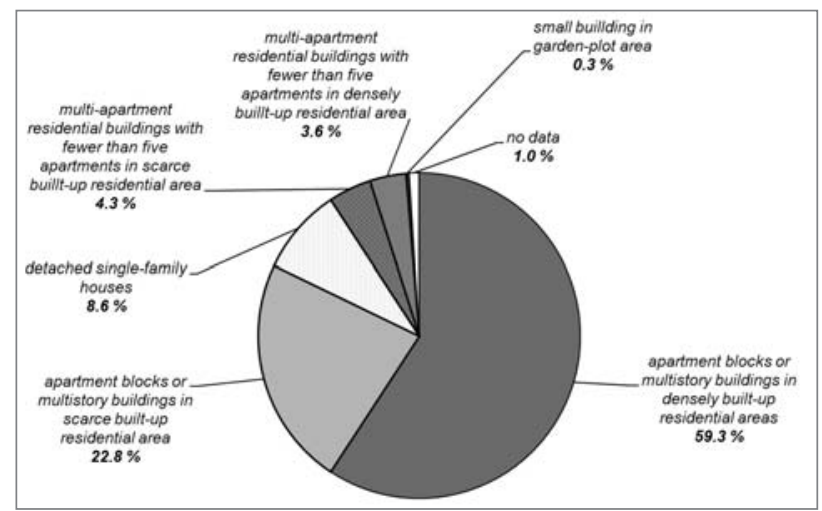

Figure 3: Residence types where members of plot-gardening households live (source: Vrščaj et al., 2008).

The majority of garden plots are in the immediate vicinity of garden-plot users' residences, which makes it possible for plot gardeners to visit their plots daily, especially taking into account that many of them are retired and a large portion are unemployed. More than two-fifths (42.1\%) of garden plots are less than a kilometer from their users' homes, and another twofifths are one to five kilometers away, which is still relatively close. Some are willing to travel great distances to reach their gardens, and one-twentieth (5.3\%) of them use gardens that are more than 10 kilometers away (ibid.).

Because distance itself affects the way in which people travel between their homes and their gardens, it is not surprising that plot gardeners reach nearby gardens less than a kilome- 
ter away on foot (44.6\%), and they usually travel to slightly more remote gardens by bicycle (26\%). Just under one-sixth (16.2\%) of plot gardeners drive cars to their garden plots; this is the most frequent way of reaching the remotest garden plots. Even though motorcycles and mopeds are becoming less common means of transportation, they are still a relevant means of transportation (6.8\%) due to the older plot-gardening population and the inflexibility connected to this. Only slightly fewer plot gardeners (5.7\%) use urban public transportation to travel from their homes to their gardens; in this case, the city bus (ibid.).

\section{Reasons for plot gardening}

Plot gardening in cities may be explained based on findings about the developmental connection of people and nature, expressed in people's need to maintain contact with nature. This need is met very individually, and is extremely intangible. On the one hand, plot gardening meets the need for genuine and direct contact between "hemmed in" city-dwellers and nature, and the desire for recreation, relaxation, and physical activity. On the other hand, one must look for reasons for the popularity of plot gardening in the existential and environmental aspects of the phenomenon (Simoneti et al., 1997). The urban population is generally known for having a sense that it can no longer affect its living environment.

The plot gardeners surveyed (Vrščaj et al., 2008) mainly use plot gardening as a means of recreation and relaxation (29\%), followed by meeting the need for physical activity (20\%). For one-fifth or $20 \%$ of plot gardeners surveyed, plot gardening is a means of healthy food production. We found it quite interesting that only just under one-tenth (or 9\%) of plot gardeners surveyed consider plot gardening a means of food production for subsistence reasons. A similar percentage consider it a leisure-time activity (Figure 4).

It is interesting that in 2007 (ibid.), despite the harsh measures taken that year against illegal garden plots in certain gardenplot areas in Ljubljana, well over half of all garden-plot users surveyed are still happy with plot-gardening conditions in Ljubljana. The percentage of positive responses was an incredible $63.3 \% .11 .6 \%$ of garden-plot users were even very satisfied, and only about one-tenth (8.9\%) were extremely dissatisfied.

Among the basic problems of garden-plot users is polluted produce along traffic routes and damage to gardens caused by passersby. The plot gardeners surveyed are also bothered by produce theft, damage caused by wildlife, lack of water in the area, noise from nearby freeways, railways, and factories, the smell from nearby municipal waste landfills, and insufficient infrastructure. Some are also bothered by the area's unkempt

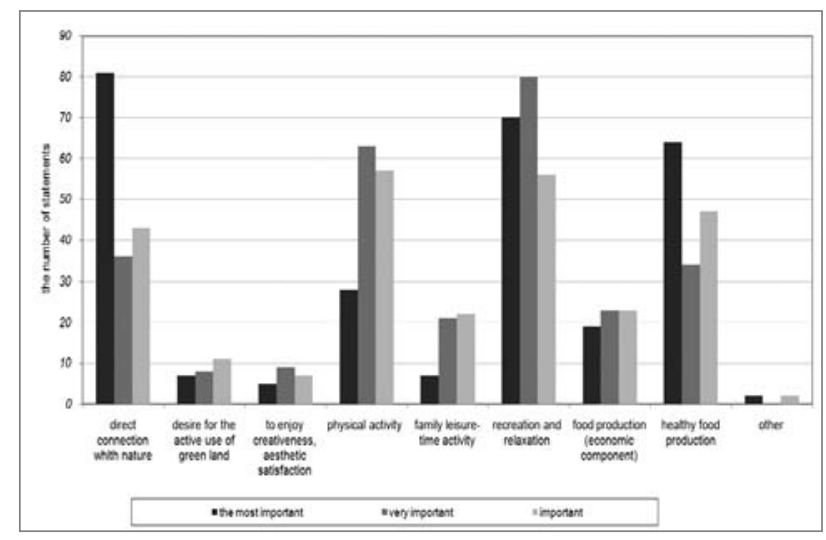

Figure 4: Main reasons for plot gardening (source: Vrščaj et al., 2008).

appearance. They also mention damage to garden-plot structures, vandalism, carousing on garden plots, dogs trampling the gardens, waste accumulation, unsuitable pesticide use, unregulated parking, limited access due to poor driveways, and the distance between homes and gardens in connection with heavy traffic and time-consuming access on the one hand, and poorer mobility of older garden-plot users on the other. They are also annoyed by the typical Slovenian "value" of envy (ibid.).

\section{5 "The plot-gardening war" and planned or controlled plot- gardening efforts}

Despite efforts to systematically eradicate the negative effects of plot gardening, piecemeal measures were taken in recent years by the city government, even before a comprehensive solution in some garden-plot areas was reached. Despite the lack of expert opinions and outdated legislation (from the mid-1980s), a dispute between the mayor of Ljubljana and plot gardeners began in April 2007, named by some media the "plot-gardening war." The campaign against garden plots began near Ljubljana's Žale Cemetery due to the conviction that the collection of shacks was out of place in the immediate vicinity of the significant European cultural heritage site represented by Plečnik's architectural creations at Žale Cemetery (Internet 1). The reasons for removing the plots was not only the neglected appearance of some garden plots, but also the fact that many gardeners had set up their plots on municipal land, for which they were not paying rent.

By removing controversial garden-plot areas, the city government began taking measures with the objective of reducing current spontaneous plot gardening from the existing $1.30 \mathrm{~km}^{2}$ of land to a smaller planned garden-plot area, $0.55 \mathrm{~km}^{2}$ in size, which did, however, include adequate infrastructure (City Municipality of Ljubljana, 2008). In addition to cultivating a pleasant environment along the roads leading into the city 
during Slovenia's presidency of the EU in 2008, another reason for managing and regulating plot gardening was certainly the fact that garden-plot areas contain numerous wells (a potential means of groundwater contamination) for watering and irrigating vegetables in garden plots. In the garden-plot area on the left bank of the Sava River south of Črnuče alone there were approximately 400 wells (Smrekar and Kladnik, 2007). There, garden plots began to be removed in the fall of 2008 .

The city government urged the plot gardeners - who had created an actual settlement with streets and homemade house numbers on the left bank of the Sava River - to voluntarily remove their huts. If they failed to do so, this would be done by the city at the garden-plot users' expense. Hot tempers and police intervention was followed by the removal of the huts, which was halted even before winter due to a lack of funds. Presumably the City Municipality of Ljubljana will continue removing the huts in 2009.

The recently proposed draft Regulation on the Management and Leasing of Garden Plots dedicates much attention to environmental protection, and so only rainwater is supposed to be used for watering garden plots (Internet 2). Ljubljana city councilors adopted it unanimously at the beginning of 2009 . Among other things, this regulation seeks to prevent these garden plots from continuing to mar Ljubljana's image, and to stop the construction of an actual vacation shantytown, which is certainly not the basic purpose of plot gardening. As recorded in the draft regulation, the municipality will lease city-owned allotments in temporary and permanent locations intended to encourage plot gardening. A new definition states that community gardens are special green areas that will no longer be located in local water-protection areas, in the city center, or in more exposed locations that might mar Ljubljana's image. Garden plots will therefore no longer appear in the vicinity of cultural monuments or cemeteries.

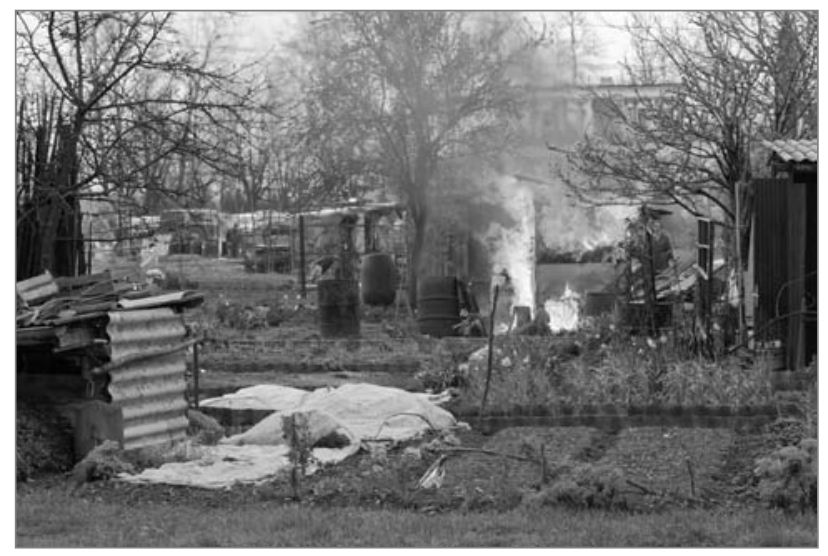

Figure 5: As a token of rebellion, many plot gardeners simply burned their huts in front of Žale Cemetery, leaving behind them utter devastation (photo: Bojan Erhartič).

\section{Assessing planned garden locations}

The newest draft of the Ljubljana Zoning Implementation Plan (City Municipality of Ljubljana, 2008) foresees more than 30 community garden locations in Ljubljana. The expert opinion and the construction conditions for these gardens were prepared by the Ljubljana Urban Planning Institute (Simoneti et al., 2007). The municipal zoning plan that is supposed to replace all current spatial acts has not yet been adopted; however, a draft of the Zoning Implementation Plan very clearly determines which plots of land may be used for plot gardening. These are defined in Article 92 of the draft as "/.../ areas intended for recreational vegetable growing and growing ornamental plants for personal use" (City Municipality of Ljubljana, 2008). Approximately half of the gardens mentioned in the Zoning Implementation Plan are to be located in existing garden-plot areas, and the other half in completely new areas (Figure 6).

The assessment of the suitability of garden areas was carried out taking into account two aspects. The first is the evaluation of suggested areas on the basis of the expert opinion and the (garden-plot) users' expectations, with a final estimate on the suitability of their location. This is based on a quantitative procedure, in which we considered all of the significant indicators that affect the suitability of plot location. The second aspect is based on analysis of land ownership in the suggested garden areas. Our analysis in based on the assumption that, if land and ownership is too fragmented, this makes collective planning and regulation of these areas difficult. Therefore, we decided to use the digital land register of the City Municipality of Ljubljana to study the ownership structure of the anticipated garden areas in greater detail.

In planning garden-plot locations, familiarity with location suitability factors is extremely important. Garden-plot locations are the result of numerous factors, varying in their levels of significance; being familiar with them is a great advantage in planning new locations. This is the only way to ensure that new locations will truly come alive and meet the needs of the population. Otherwise, garden plots may once again begin spreading outside of the planned areas, to locations users consider more desirable.

\subsection{Methodology}

The criteria for determining the suitability of community garden areas was established in the draft Zoning Implementation Plan, especially on the basis of survey results and the expert opinion. They may be divided into exclusion and attraction criteria.

Using criteria known as exclusion criteria, we checked whether there are locations among the suggested garden areas that are 
completely unsuitable based on legislative, urban-planning, health, or environmental grounds. These include the most sensitive local water-protection areas, locations within the historical city center, and locations in the immediate vicinity of watercourses, waste landfills, and major traffic routes, which can significantly influence the quality and consequently the safety of the food produced. Exclusion indicators are the "minimum" standard that new garden-plot areas should be able to meet entirely because they have been determined on the basis of the expert opinion and legislative restrictions.

The criteria known as attraction criteria are used to define the potential attraction that garden plots might have to users. These are extremely important because the conditions in new garden areas must suit both the users and the wider community. If the users think that community gardens were placed in unsuitable locations, this may result in new illegal garden plots that the users (plot gardeners) deem more suitable. These criteria were established with the help of a survey among garden-plot users, in which we appropriately weighted individual location factors depending on the weight of the answers in the survey. For example, those surveyed cited accessibility as a significant factor in garden-plot location. A full two-thirds answered that this circumstance is the most important. The majority of the garden-plot users surveyed (82\%) think that a distance up to five kilometers would be acceptable, and this is almost completely in agreement with the current state of garden-plot users surveyed. $83 \%$ of them actually live less than five kilometers from their garden plot. The survey results thus indicate that garden-plot users would not tolerate worse accessibility, which should most certainly be considered in planning new locations. Some of the most important factors are also soil fertility and distance from traffic routes, and less important factors include the general attractiveness of the landscape, such as the vicinity of woods and rivers, as well as sociability and quietness. Accessibility indicators were thus determined on the basis of the survey answers, and we also took into consideration access to public transportation because public transportation plays a significant role in the Ljubljana spatial plan as the only real alternative to less popular personal transportation. The least important factor proved to be access to watercourses. Thus, its weight in determining overall suitability was correspondingly reduced.

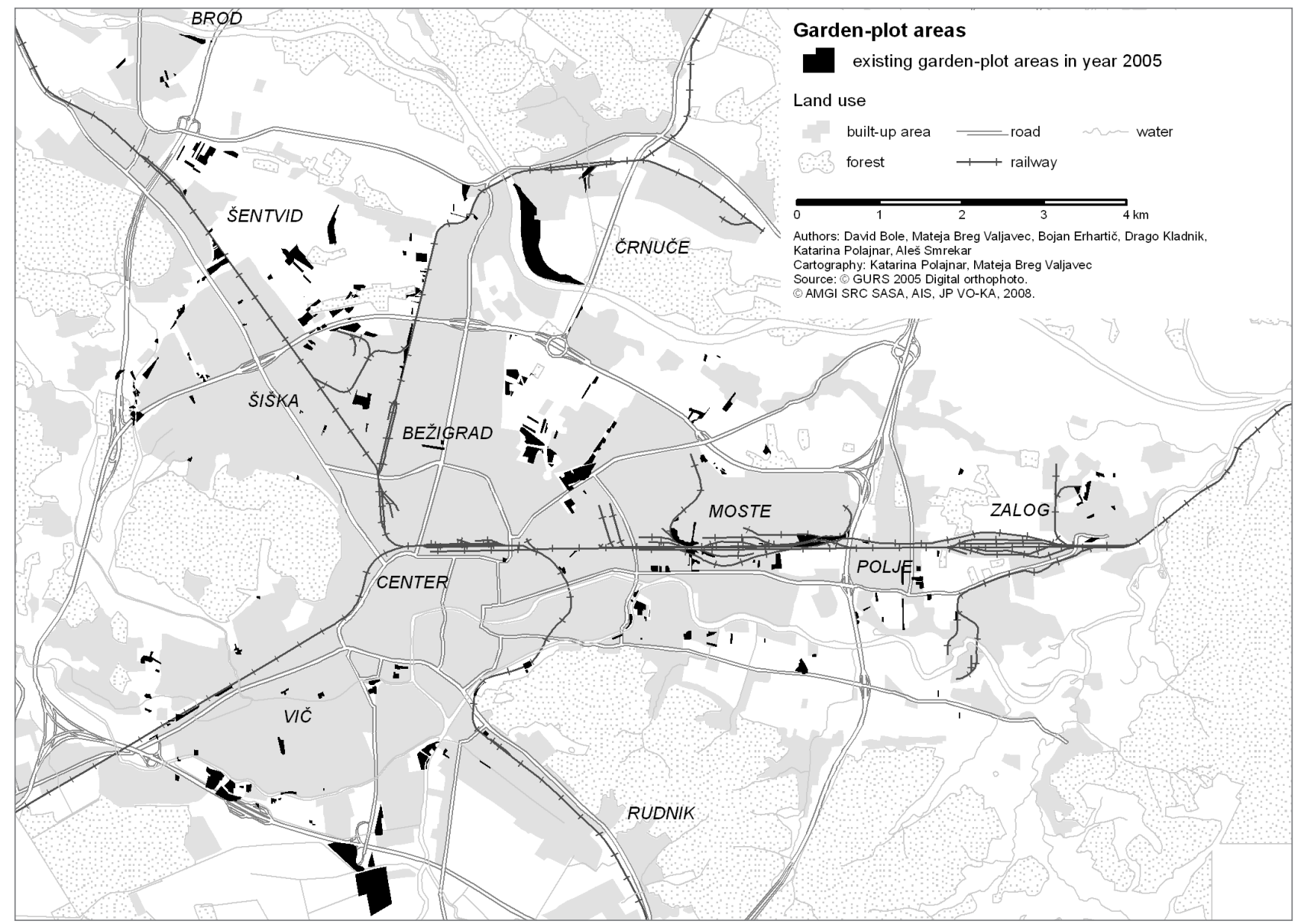

Figure 6: Garden-plot locations in 2005, and the anticipated garden-plot locations from the City Municipality of Ljubljana Zoning Implementation Plan (source: Vrščaj et al., 2008). 
Table 2: Exclusion and attraction criteria by contribution to overall assessment of attractiveness.

\begin{tabular}{lll}
\hline & Criterion name & Total percentage of attraction assessment \\
\hline I. & \multicolumn{1}{c}{ Exclusion criteria } \\
\hline 1. & Outside the city center & $/$ \\
\hline 2. & Outside an immediate water-protection area (WPA I) & $/$ \\
\hline 3. & Outside an immediate watercourse area (50 $\mathrm{m})$ & $/$ \\
\hline 4. & Outside an immediate wooded area and waste landfill area $(100 \mathrm{~m})$ & $/$ \\
\hline 5. & $\begin{array}{l}\text { Outside an immediate traffic route area (freeway } 100 \mathrm{~m} \text {, regional road } 30 \mathrm{~m}, \text { rail- } \\
\text { way } 30 \mathrm{~m})\end{array}$
\end{tabular}

II. Attraction criteria

\section{Accessibility, facilities}

A Distance from apartment block neighborhood

Up to $1,000 \mathrm{~m}=5$ points

1,000 to $2,000 \mathrm{~m}=4$ points

2,000 to $3,000 \mathrm{~m}=3$ points

3,000 to $4,000 \mathrm{~m}=2$ points

4,000 to $5,000 \mathrm{~m}=1$ point

Over $5,000 \mathrm{~m}=0$ points

B Distance from public transportation stop

$10 \%$

Up to $300 \mathrm{~m}=3$ points

300 to $600 \mathrm{~m}=2$ points

600 to $1,000 \mathrm{~m}=1$ point

Over $1,000 \mathrm{~m}=0$ points

C Municipal infrastructure: water, sewage

$10 \%$

Equipped with water and sewage $=4$ points

Equipped with water or sewage, and a water or sewer connection point up to 100

$\mathrm{m}$ away $=3$ points

Equipped with water or sewage, and a water or sewer connection point over 100

$\mathrm{m}$ away $=2$ points

Water or sewer connection points up to $100 \mathrm{~m}$ away $=2$ points

Water or sewage connection points over $100 \mathrm{~m}$ away $=1$ point

Water or sewer connection points, both more than $100 \mathrm{~m}$ away $=0$ points

D Distance from watercourse

$5 \%$

Up to $100 \mathrm{~m}=2$ points

100 to $200 \mathrm{~m}=1$ point

Over $200 \mathrm{~m}=0$ points

\section{Health, soil fertility}

A Suitability of soil for plot gardening

\section{Total: $45 \%$}

Very suitable soil $=4-5$ points

Suitable soil $=3-4$ points

Suitable and less-suitable soil $=2-3$ points

Less-suitable and unsuitable soil $=1-2$ points

Questionable soil $=$ less than 1 point

\section{Total: $50 \%$}

$25 \%$ 


\begin{tabular}{|c|c|c|}
\hline B & Distance from traffic route & $15 \%$ \\
\hline & \multicolumn{2}{|l|}{ Over $1,000 \mathrm{~m}=3$ points } \\
\hline & \multicolumn{2}{|l|}{500 to $1,000 \mathrm{~m}=2$ points } \\
\hline & \multicolumn{2}{|l|}{100 to $500 \mathrm{~m}=1$ point } \\
\hline & \multicolumn{2}{|l|}{ Up to $100 \mathrm{~m}=0$ points } \\
\hline \multirow[t]{5}{*}{ C } & Distance from industrial facilities & $10 \%$ \\
\hline & \multicolumn{2}{|l|}{ Over $1,000 \mathrm{~m}=3$ points } \\
\hline & \multicolumn{2}{|l|}{500 to $1,000 \mathrm{~m}=2$ points } \\
\hline & \multicolumn{2}{|l|}{100 to $500 \mathrm{~m}=1$ point } \\
\hline & \multicolumn{2}{|l|}{ Up to $100 \mathrm{~m}=0$ points } \\
\hline \multirow[t]{5}{*}{ D } & Distance from other intensive activities (shopping center, business district, etc.) & $5 \%$ \\
\hline & \multicolumn{2}{|l|}{ Over $1,000 \mathrm{~m}=3$ points } \\
\hline & \multicolumn{2}{|l|}{500 to $1,000 \mathrm{~m}=2$ points } \\
\hline & \multicolumn{2}{|l|}{100 to $500 \mathrm{~m}=1$ point } \\
\hline & \multicolumn{2}{|l|}{ Up to $100 \mathrm{~m}=0$ points } \\
\hline \multicolumn{2}{|c|}{ 3. Effects on the environment } & Total $5 \%$ \\
\hline A & Suitable distance from built-up areas (up to $200 \mathrm{~m}$ ) & $2.5 \%$ \\
\hline & \multicolumn{2}{|l|}{ Over $200 \mathrm{~m}=2$ points } \\
\hline & \multicolumn{2}{|l|}{100 to $200 \mathrm{~m}=1$ point } \\
\hline & \multicolumn{2}{|l|}{ Up to $100 \mathrm{~m}=0$ points } \\
\hline \multirow[t]{5}{*}{ B } & Wider water-protection area (WPA Ila, IIb, III) & $2.5 \%$ \\
\hline & \multicolumn{2}{|l|}{ Outside a WPA $=3$ points } \\
\hline & \multicolumn{2}{|l|}{ WPA III = 2 points } \\
\hline & \multicolumn{2}{|l|}{ WPA $\| \mathrm{lb}=1$ point } \\
\hline & WPA $\| l a=0$ points & \\
\hline
\end{tabular}

Note: WPA = water-protection area.

Some of the community garden attraction criteria include factors such as health and soil fertility. According to the survey results, soil suitability has the greatest significance; slightly less important is the distance from major pollution sources, such as traffic routes, industrial areas, and other areas of intensive activity. These include shopping centers, which are accompanied by heavy traffic. In determining traffic routes, we took into account primary traffic routes, such as freeways, expressways, regional roads, and railways. Soil suitability was estimated on the basis of organic matter levels, heavy metal contamination, depth, and texture.

The final category of attraction criteria was titled "effects on the environment." This category covers the smallest percentage of the overall assessment. Its weight is determined on the basis of the expert opinion, and it includes two indicators that affect the general state of the environment. From the visual point of view, it is important to ensure at least a minimal distance of garden areas from land already built-up, or land intended for construction. A small portion of the overall assessment is also the location in various water-protection areas because garden areas should not have a significant negative effect on groundwater quality even in wider water-protection areas.

\subsection{Results of the suitability assessment of planned garden-plot areas, as recorded in the Draft City Municipality of Ljubljana zoning implementation plan}

The process of assessing suitability of planned garden-plot locations took place in two phases. The first phase used exclusion criteria to assess which areas suggested in the Zoning Implementation Plan are partially or completely unsuitable based on health, legislative, and urban-planning grounds. The second phase also assessed the suitability of individual areas from the viewpoint of attractiveness to users (plot gardeners) on the basis of attraction criteria.

We first checked whether the anticipated locations fit the exclusion criteria. All five criteria are entirely met by locations outside the city center, far enough from traffic routes, watercourses, waste landfills, woods, and the immediate water-protection area. Suitable distance from larger watercourses (the Sava, Ljubljanica, Glinščica, Gradaščica, Mali Graben, and Ižica) is partially disputable in two locations where more than $10 \%$ of the garden area extends $50 \mathrm{~m}$ into the border strip. These are garden plots in the immediate vicinity of the Sava River in 
Šiška (marked ŠE-309) and Mali Graben (TR-122). Traffic routes proved to be the most important exclusion criterion because four anticipated garden areas do not completely meet the set criteria. The two garden areas in Vič are in the immediate vicinity of a railway and a major radial road, and the areas along the Sava (ŠE-309) and along Cesta dveh cesarjev (Two Emperors Street) (TR-100) are too near the freeway.

The map marks the community garden locations that are either completely unsuitable because they do not entirely meet one or more criteria, or partially suitable ones that partially meet the set criteria (e.g. $90 \%$ of the garden area is outside the restricted area, and $10 \%$ is within it). Three garden areas are completely unsuitable because they do not meet the criteria of suitable distance from major traffic routes, and two areas are partially suitable because they do not entirely meet the criteria of distance from major watercourses (Figure 7).

The second phase checked accessibility, equipment, health, soil fertility, and environmental criteria. These are attraction criteria that attempt to answer which planned garden areas are more or less suitable based on the expectations of plot gardeners themselves, and partly on the basis of expert assessment. Especially in the case of less-suitable areas, a new assessment on the suitability of these situations by spatial planners would be reasonable.

Favorable spatial accessibility is most frequently mentioned in connection with the "attractiveness" of individual garden plots. Because garden-plot users are mostly residents of major residential areas, we checked the average distance between apartment block neighborhoods and the anticipated community garden areas. Apartment block neighborhoods were digitalized on the basis of a prior morphological analysis (Rebernik, 2000). The main finding was that accessibility is good. Exceptions are the ŠE-309 area in the far north of Ljubljana, and the completely new planned areas along the Ljubljanica River, marked RN. The majority of other anticipated garden areas are less than one kilometer from major apartment block neighborhoods.

Accessibility to public transportation is slightly worse. Again, there is extremely poor accessibility in the far northern area of Ljubljana, as well as in areas in Koseze with above-average distances from public transportation stops. These areas also stand out due to poorer outfitting with basic infrastructure (water and sewage), which means that construction would be necessary to ensure at least basic municipal infrastructure.

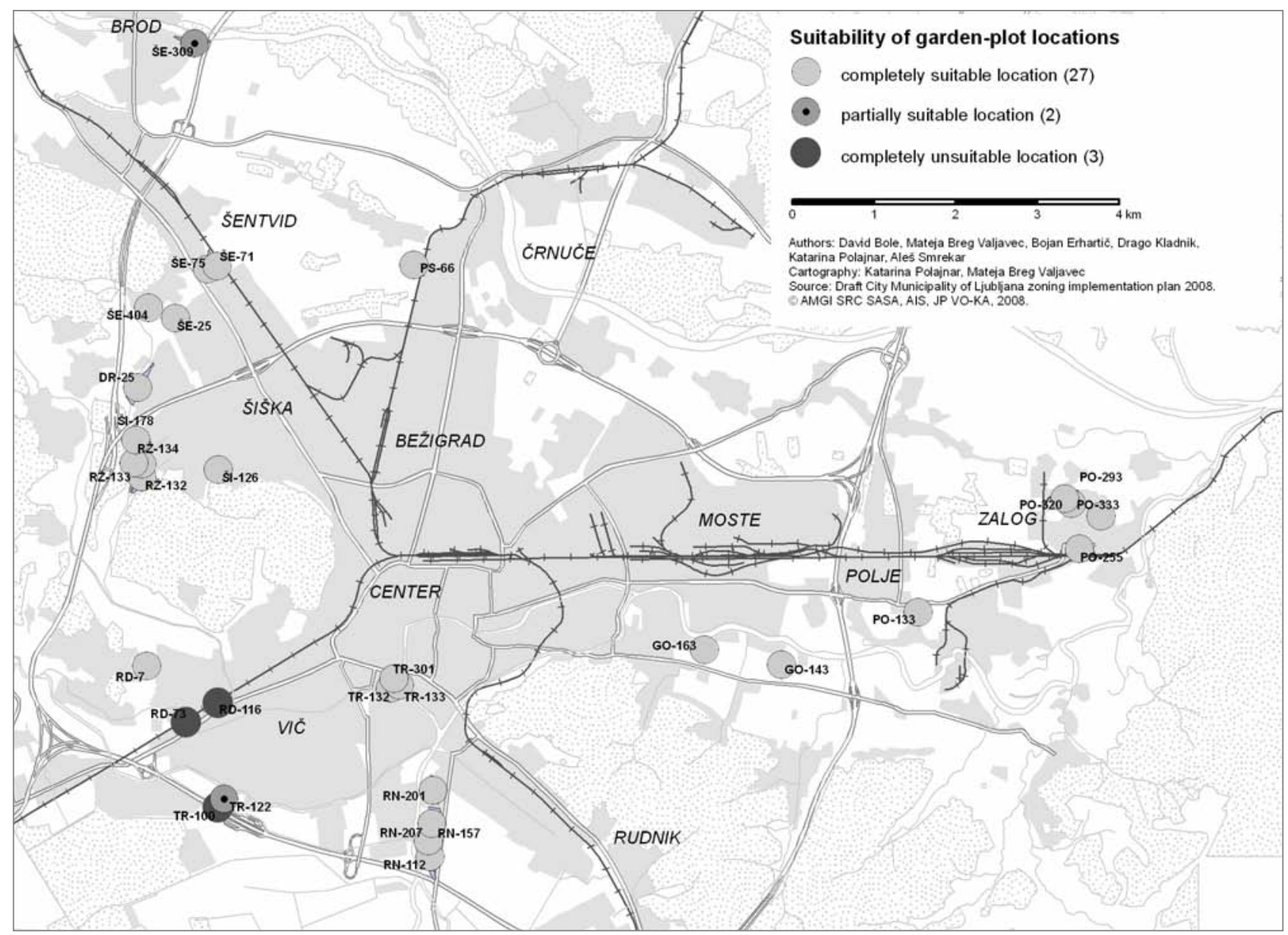

Figure 7: Suitability of garden areas anticipated in the draft Zoning Implementation Plan by exclusion criteria (source: Vrščaj et al., 2008). 
The overall weighted assessment of soil suitability indicates that garden areas in Livada (RN) have the most suitable soil, and the least suitable soil in the suburban area of Krakovo (TR-301, TR-132, and TR-133), where the soil is less suitable or unsuitable for garden plots. The soil in the Vič area (RD-73 and $\mathrm{RD}-116)$ is also less suitable.

Distance from traffic routes is important when considering the health of garden-plot users. They mostly grow vegetables for personal use, and perceive the vicinity of freeways and other traffic routes as a negative factor. The majority of the anticipated community garden areas are far enough from traffic routes; only the two areas along Celorskka cesta (Klagenfurt Street) in Šška (ŠE-71 and ŠE-75) stand out because they are in the immediate vicinity of a major radial road, the railway, and a freeway. As far as the distance from anticipated industrial activities is concerned, garden area PO-320 directly bordering the Zalog industrial zone has an exceptionally bad location.

In determining suitability, environmental effects have the lowest point value because garden plots usually do not have a negative effect on the environment. This can also be said about the esthetic aspect, assuming that the gardens are appropriately designed and placed in an area that would be complemented by a planned community garden.

An overall synthetic assessment on the basis of attraction criteria was fairly favorable for the planned garden areas because all of the locations scored more than a half of the 33 possible points. Nonetheless, certain differences can be noticed. The least suitable are the garden areas in Šška and Polje, especially due to the disadvantageous vicinity of major traffic routes and unsuitable soil. Together, these two criteria contribute to more than one-third of the total assessment, and therefore greatly contribute to the lower score of all three garden areas mentioned. For various reasons, garden areas in Vič, along the Sava River, and in Bežigrad scored between 69\% and 75\% of the total possible points. Access to the garden area along the Sava River is difficult and it is quite far from apartment block neighborhoods, the area in Vič scored lower because it is near traffic routes and has poor soil, and the area in Zalog scored low due to the immediate vicinity of the Zalog industrial zone.

One of the most attractive garden areas is the one in Livada (marked RN). It scored well because of its high-quality soil, already existing water and sewage connections, and a suitable

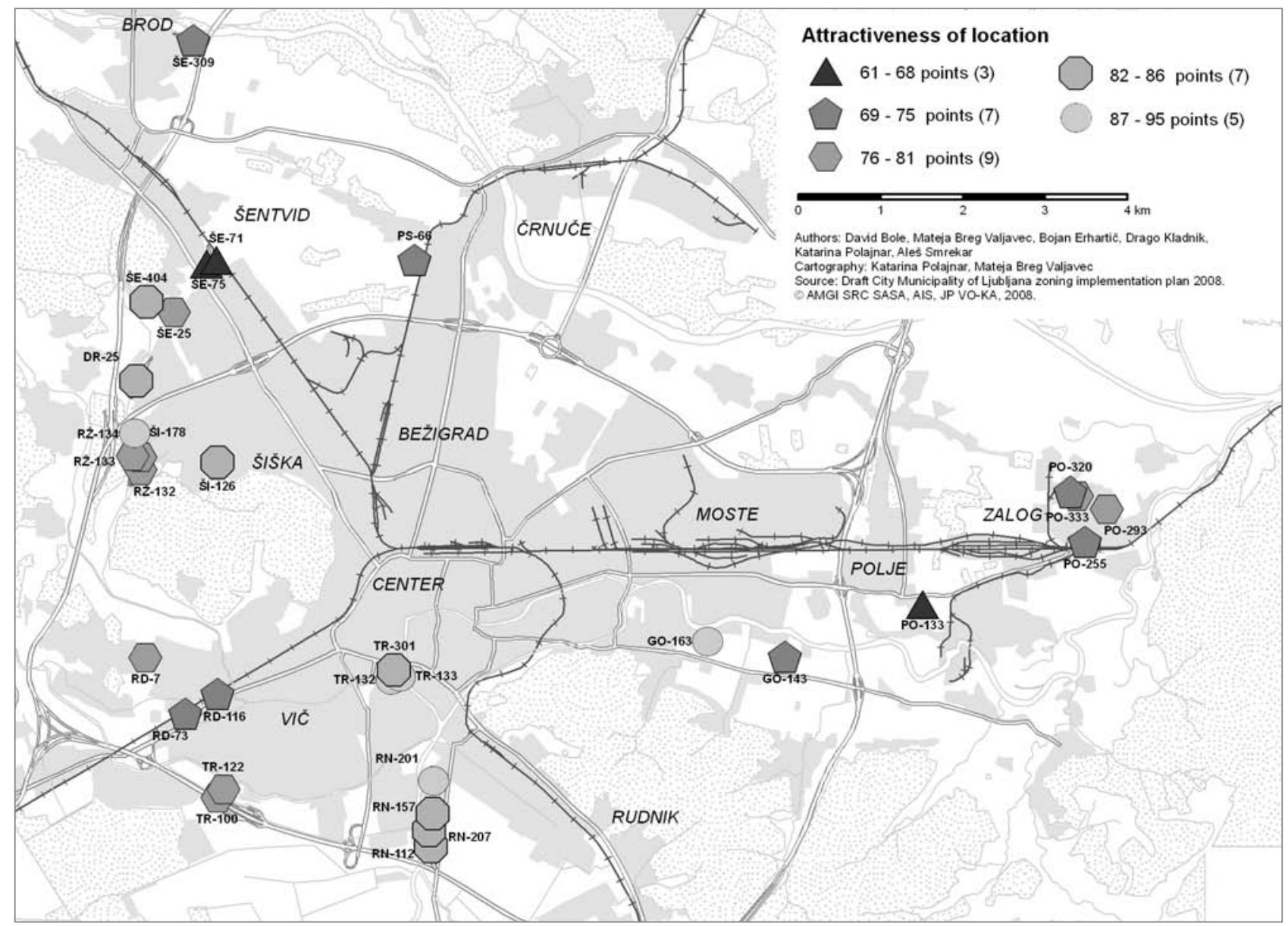

Figure 8: Scoring system for anticipated garden areas by attraction criteria, as recorded in the draft City Municipality of Ljubljana Zoning Implementation Plan (source: Vrščaj et al., 2008). 
distance from unfavorable factors (traffic routes, industrial zones, etc.). This area's disadvantage is a slightly greater distance from apartment block neighborhoods. Very high scores were also received by the now traditional garden-plot areas in Krakovo, and individual scattered garden-plot areas such as those in Štepanjsko Naselje and Šiška (Figure 8).

\subsection{Ownership structure of anticipated garden-plot areas, as recorded in the Draft City Municipality of Ljubljana zoning implementation plan}

From the viewpoint of successful spatial placement of community garden areas, optimal ownership structure of allotments included is desired. The fulfillment of various infrastructure, esthetic, and other regulatory conditions also depends on the ownership of land intended to be organized into garden areas. The ownership structure should be as uniform as possible. Circumstances are most favorable when the City Municipality of Ljubljana owns the largest portion of an area because the possibility for uniform arrangement, management, and connection to appropriate infrastructure is greater than when an area is divided among a group of smaller private land owners. The City Municipality of Ljubljana will lease the allotments and require payment for operational and maintenance costs from the tenants for a period of one to five years (Petkovšek, 2009).

The draft Zoning Implementation Plan assessed the ownership structure of garden areas with the help of a digital cadastral plan of the City Municipality of Ljubljana. The ownership of Ljubljana's parcels was divided into four basic groups:

- Parcels exclusively owned by the City Municipality of Ljubljana or institutions closely connected to it (the Ljubljana Housing Fund, "old" municipalities, such as Ljubljana-Center, and so on),

- Parcels exclusively owned by the state, certain government institutions, or companies closely connected to it (e.g., the Ministry of Defense, Slovenian Railways, the Slovenian Restitution Fund, and so on),

- Parcels predominantly owned by private citizens or private companies,

- Parcels in the category "other," with mixed ownership (state/municipality/private owners), public domain, or unknown ownership.

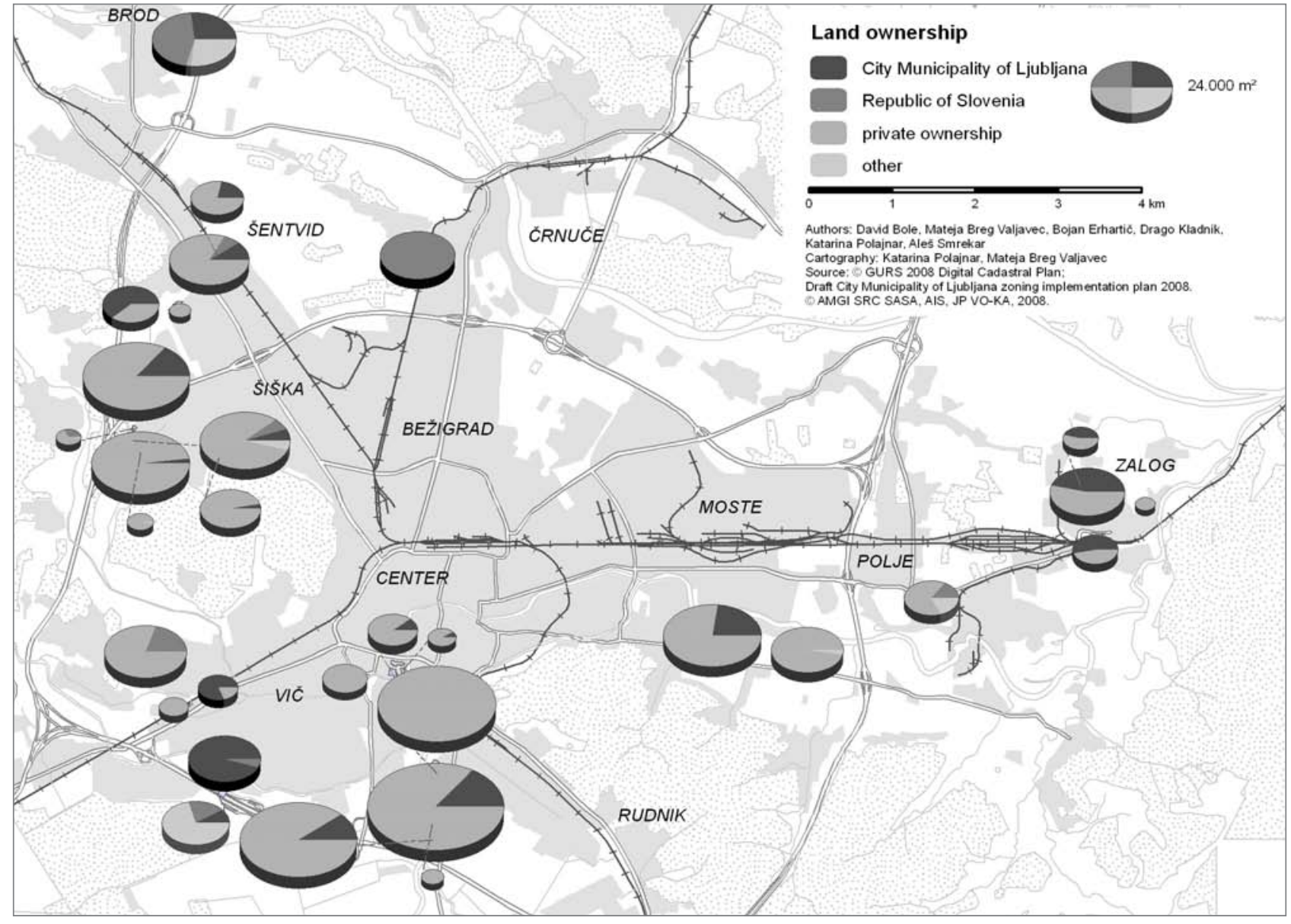

Figure 9: Ownership structure in garden areas anticipated in the draft City Municipality of Ljubljana Zoning Implementation Plan (source: Vrščaj et al., 2008). 
The ownership structure in the anticipated garden areas is quite unfavorable (Figure 9). A full $72 \%$ of parcels are owned by private citizens, and the City Municipality of Ljubljana owns only $16 \%$. Together with state ownership, less than one-fifth of land is publicly owned, which may prove to be a major obstacle for uniform organization and outfitting of planned garden areas. In figures, this means that the city owns just over $87,000 \mathrm{~m}^{2}$, the state $45,000 \mathrm{~m}^{2}$, and private citizens a full $402,000 \mathrm{~m}^{2}$ of land in anticipated garden areas.

A cartographic representation of ownership structure reveals differences between individual areas. The largest percentage of parcels owned exclusively by the city is in the anticipated garden areas in Zalog and certain areas in Vič. In 24 of the 31 areas, the city does not own even one-fourth of their entire anticipated area. The state has exclusive ownership in only one of the planned areas (Savlje), where the Ministry of Defense is recorded as the sole proprietor in the land register. The only other area in which the state owns a substantial portion is in the area along the Sava River.

In 23 of the 31 garden areas recorded in the draft City Municipality of Ljubljana Zoning Implementation Plan, more than half of land is privately owned. Individuals in particular stand out, and in rare cases legal entities are also major owners, among which construction and real estate companies prevail. The largest areas are also predominantly privately owned. The largest garden areas are anticipated in Livada, where the portion of land owned by the city and state is less than one-fifth. Private ownership also prevails in the larger garden areas anticipated in Šiška, Dravlje, and Koseze.

The ownership structure of garden areas is thus a potential problem. The City Municipality of Ljubljana controls only a small portion of land, and thus has a very limited possibility of regulating these areas in a uniform manner. Even obtaining this land might prove to be problematic, expensive, and timeconsuming. The purchase of $400,000 \mathrm{~m}^{2}$ of privately owned land is a large financial undertaking, and so the city government will probably have to consider establishing a partnership between public and private owners in the anticipated garden areas. In light of past disagreements, it is certainly necessary to attempt to reach a consensus among the city, land owners, and garden-plot users. It will also be necessary to more closely involve both the general public and experts.

\section{Conclusion}

More than three-quarters (77.8\%) of Ljubljana's garden-plot users plan to continue plot gardening, at least for the next five years. Such determination is somewhat surprising considering their age structure; however, this contains a hidden desire to continue what they consider an activity of vital importance, and maintaining their lifestyle. Only 2.6\% stated that they plan to keep their garden plot for one year or less (Vrščaj et al., 2008).

Among the garden-plot users surveyed, $44.3 \%$ are willing to replace an existing garden plot with a suitably furnished allotment in (from the city's perspective) a more suitable location. $47.0 \%$ are unwilling to do so. Just under one-tenth (8.7\%) of users are undecided. Considering their age and education, there are no evident differences between individual categories of garden-plot users. If the quality of food produced in an existing garden plot were unsuitable, a full two-fifths (41.7\%) of garden-plot users surveyed would be willing to use an allotment in a different location. The rest are completely satisfied with the current location of their garden plots, and would not agree to replace them even in the case of reduced food quality. A full tenth (11.0\%) have not yet formed an opinion on the matter. The level of willingness to move is much higher among more educated garden-plot users (Vrščaj et al., 2008).

Internal differentiation is evident among individual gardenplot areas. The vast majority of garden-plot users ready to replace their gardens are in areas along Hradeckega cesta (Hradecky Street) under Golovec Hill, Krakovska ulica (Krakovo Street) in Krakovo, Gramozna pot (Gravel Way) in Fužine, and Ulica Jožeta Jame (Jože Jama Street) in Upper Šiška, and more than $50 \%$ positive responses were recorded in areas along Aleševčeva ulica (Aleševc Street) in Bežigrad, Litostrojska cesta (Litostroj Street) in Šš̌ka, Saveljska cesta (Savlje Street) in Sa-

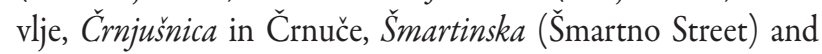
Letaliska cesta (Airport Street) in Moste, Cesta Dolomitskega odreda (Dolomite Detachment Street) in Brdo, and Cesta dveh cesarjev (Two Emperors Street) in Vič. There are, however, areas where garden-plot users that are not ready for such replacement prevail. Areas that stand out are along Vrtnarska cesta (Gardeners' Street) in Šentvid, Kranjčeva ulica (Kranjc Street) in Bežigrad, Agrokombinatska cesta (Agrokombinat Street) in Zalog, in Štepanjsko Naselje, along Cesta na Brdo (Brdo Street), along Curnovec Creek in Rakova Jelša, and Cesta na Vrhovce (Vrhovci Street) and Hladnikova cesta (Hladnik Street) in Trnovo (Vř̌čaj et al., 2008).

The plot gardeners' resistance to moving is an important circumstance that will need to be taken into account when planning new areas. This means that decision-making by consensus, inclusion of public stakeholders, and establishing dialog between the city government and garden-plot users will need to be ensured in preventing the escalation of mutual distrust and opposition. This might mean that it might be sensible to 
retain some existing (renovated) garden-plot areas - of course, only if they meet all location and other restrictive criteria.

Dr. David Bole, Geographer, Research Associate

Anton Melik Geographical Institute of the Slovenian Academy of Sciences and Arts Scientific Research Center, Ljubljana, Slovenia E-mail: david.bole@zrc-sazu.si

Mateja Breg Valjavec, Geographer, Assistant Anton Melik Geographical Institute of the Slovenian Academy of Sciences and Arts Scientific Research Center, Ljubljana, Slovenia E-mail: mateja.breg@zrc-sazu.si

Bojan Erhartič, Geographer, Assistant

Anton Melik Geographical Institute of the Slovenian Academy of Sciences and Arts Scientific Research Center, Ljubljana, Slovenia E-mail:bojaner@zrc-sazu.si

Dr. Drago Kladnik, Professor of Geography and History, Senior Research Associate

Anton Melik Geographical Institute of the Slovenian Academy of Sciences and Arts Scientific Research Center, Ljubljana, Slovenia E-mail: drago.kladnik@zrc-sazu.si

Katarina Polajnar, Geographer, Assistant Anton Melik Geographical Institute of the Slovenian Academy of Sciences and Arts Scientific Research Center, Ljubljana, Slovenia E-mail: katarina.polajnar@zrc-sazu.si

Dr. Aleš Smrekar, Geographer and Ethnologist, Research Associate Anton Melik Geographical Institute of the Slovenian Academy of Sciences and Arts Scientific Research Center, Ljubljana, Slovenia E-mail: ales.smrekar@zrc-sazu.si

\section{Acknowledgements}

This article is the result of the research project Plot gardening in the City Municipality of Ljubljana as a pollution source for soil, food produced, and groundwater carried out by researchers at the Anton Melik Geographical Institute of the Slovenian Academy of Sciences and Arts Scientific Research Center, the Agricultural Institute of Slovenia (coordinating institute), and the public company Vodovod - kanalizacija d.o.o. We would like to thank the City Municipality of Ljubljana Office for Development Projects for providing funding.

\section{References}

City Municipality of Ljubljana (2008) Izvedbeni prostorski načrt Mestne občine Ljubljana. Available at: http://urbanizem.ljubljana.si/ index.htm (Date accessed 18. 4. 2008).

Christl, I., Gultz, P. A., Kretzschmar, R., and Schulin, R. (2004) Umgang mit bodenbelastungen in familiengärten der stadt Zürich. Institut für terrestrische Ökologie. Zürich, Institut für terrestrische Ökologie, ETH Zürich.

Doležal, M., Strojin Božič, Z., and Turk, M. (2005) Reševanje problematike vrtičkov na območju MOL. Report No. 2. Ljubljana, Mestna občina Ljubljana.
Goriup, Z. (1984) Planiranje in urejanje območij malih vrtov (vrtičkov) $v$ Ljubljani. Plan. Ljubljana, Urbanistični inštitut Slovenije.

Gregorič, L., Hafner Petrovski, S., Maslo, G., Dežman Markič, T., Strojin, Z., and Doležal, M. (2004) Reševanje problematike vrtičkov na območju MOL. Report No. 1. Ljubljana, Mestna občina Ljubljana.

Internet 1: http://www.mk.gov.si/si/splosno/cns/novica/browse/6/ article/2130/5395/?\&tx_ttnews\%5Byear\%5D=2007\&tx_ttnews\%5Bm onth\%5D=02\&cHash=c196405f08 (Date accessed 7. 4. 2009).

Internet 2: http://www.ljubljana.si/si/mol/mestni_svet/seje/78575/ detail.html (Date accessed 3. 3. 2009).

Petkovšek, J. (2009) Potrebujemo zakon, ne le odlok. Delo, 51(24), 30. 1. 2009 , p. 9.

Rebernik, D. (2000) Morfološka zgradba. In: Gabrovec, M., and Orožen Adamič, M. (eds.): Ljubljana - geografija mesta, pp. 39-52. Ljubljana, Ljubljansko geografsko društvo, Založba ZRC.

Simoneti, M., Bevk, J., Pintar, M., Zupan, M., Gajšek, P., Golobič, M., Pleško, R., and Bevk, M. (1997) Usmeritve in pogoji za nadaljnji razvoj vrtičkarstva $v$ Ljubljani. Report about development-research project. Ljubljana, Ljubljanski urbanistični zavod.

Simoneti, M. (2000) Narava $v$ mestu - med načrtovanim in spontanim. Available at: http://www.dkas.si/?id=3,9,42 (Date accessed 17. 6. 2008).

Simoneti, M., Kranjc, U., Musek, A., Šorn, M., Vidic, L., and Dobnikar, T. (2007) Urejanje vrtičkarskih območij v Ljubljani. Expert opinions. Ljubljana, Ljubljanski urbanistični zavod.

Smrekar, A., and Kladnik, D. (2007) Zasebni vodnjaki in vrtine na območju Ljubljane. Ljubljana, Geografski inštitut Antona Melika ZRC SAZU.

Surveying and Mapping Authority of the Republic of Slovenia (2005) Digital ortofoto 2005. Ljubljana.

Surveying and Mapping Authority of the Republic of Slovenia (2008) Digital cadastral plan 2008. Ljubljana.

Vastl, N. (2000) Vrtičkarstvo. Specialist Work. Ljubljana, Univerza v Ljubljani, Fakulteta za arhitekturo.

Vrščaj, B., Sušin, J., Simončič, A., Markelc, I., Glad, J., Palčič, T., Smrekar, A., Bole, D., Breg, M., Erhartič, B., Kladnik, D., Polajnar, K., Jamnik, B., Nartnik, M., and Auersperger, P. (2008) Vrtičkarstvo v Mestni občini Ljubljana kot vir onesnaženosti v tleh, pridelani hrani in podzemni vodi. Plan. Ljubljana, Kmetijski inštitut Slovenije, Geografski inštitut Antona Melika ZRC SAZU, Javno podjetje Vodovod - kanalizacija, d. o. o. 